\title{
Galactose Metabolism in Regenerating Rat Liver
}

\author{
By CHRISTIAN H. BAUER, BARBARA F. HASSELS and WERNER G. REUTTER \\ Biochemisches Institut, Universität Freiburg, D-78 Freiburg, Germany
}

(Received 11 July 1975)

\begin{abstract}
1. Rats trained on a controlled lighting and feeding schedule were subjected to partial hepatectomy or sham operation. 2. After a lag period of about $6 \mathrm{~h}$ the activity of UDPgalactose 4-epimerase increased threefold, reaching a maximum 4 days after partial hepatectomy, and returned to normal values within a fortnight. 3. The enzyme pattern of the UDP-galactose-glycoprotein galactosyltransferase was biphasic, one peak appearing at $20 \mathrm{~h}$, the second at $72 \mathrm{~h}$ after partial hepatectomy. 4 . The rise in enzyme activities could be blocked by the injection of actinomycin D, and the $K_{\mathrm{m}}$ values for UDP-glucose and UDP-galactose were nearly identical in regenerating and adult liver. It is therefore concluded that the increase in enzyme activity is due to synthesis de novo of enzyme protein. 5. UDP-glucose and UDP-galactose were determined at different times after partial hepatectomy. The lowest concentration was found between $3 \mathrm{~h}$ and $6 \mathrm{~h}$ after operation (UDP-glucose: $232 \pm 32 \mathrm{nmol} / \mathrm{g}$ of liver; UDP-galactose: $72 \pm 10 \mathrm{nmol} / \mathrm{g}$ of liver); the highest value was measured between $24 \mathrm{~h}$ and $72 \mathrm{~h}$ (UDP-glucose: $385 \pm 28 \mathrm{nmol} / \mathrm{g}$ of liver; UDP-galactose: $108 \pm 9 \mathrm{nmol} / \mathrm{g}$ of liver). 6 . In unoperated animals the epimerase and galactosyltransferase exhibited daily oscillations, with maximum values at the end of the dark period.
\end{abstract}

Liver has the capacity to regenerate; within 7 days after partial hepatectomy the original liver weight is nearly restored. The mechanism responsible for the initiation of regeneration is still unknown, though extensive investigations have been undertaken to elucidate the sequence of events leading to cell division (Mayfield \& Bonner, 1972; Paul et al., 1972; Bucher \& Swaffield, 1973). Several reports have shown that RNA and DNA synthesis is induced by partial hepatectomy (Grisham, 1962; Chaudhuri \& Lieberman, 1968; Bucher \& Swaffield, 1969). At the same time the activity of a number of enzymes increases which are not involved in RNA or DNA synthesis. Among these are pyruvate kinase (EC 2.7.1.40) (Bonney et al., 1973), ornithine decarboxylase (EC 4.1.1.17) (Russell \& Snyder, 1968; Jänne \& Raina, 1968), alkaline phosphatase (EC 3.1.3.1) (Pekarthy et al., 1972), acid phosphatase (EC 3.1.3.2) (Chatterjee et al., 1974) and glutamine-fructose 6-phosphate aminotransferase (EC 5.3.1.19) (Akamatsu \& Maeda, 1971). Nothing is known about the activity of galactose-metabolizing enzymes during liver regeneration.

The present study has been undertaken to characterize the role of galactose metabolism in regenerating rat liver, because galactose is an integral constituent of glycoproteins (Eylar \& Jeanloz, 1962) and glycolipids (Henning \& Stoffel, 1973). It was decided to find out whether galactokinase (ATP-D-galactose 1-phosphotransferase, EC 2.7.1.6) and uridyltransferase (UDP-glucose- $\alpha$-D-galactose 1-phosphate uridylyltransferase, EC 2.7.7.12) respond to surgical removal of two-thirds of the liver. Since galactose is only a minor nutrient for adult animals, the necessary supply of this essential carbohydrate is obtained via the conversion of UDP-glucose into UDP-galactose, a reaction which is catalysed by UDP-galactose 4epimerase (EC 5.1.3.2). UDP-galactose is the substrate for the galactosyltransferase (UDP-galactoseglycoprotein galactosyltransferase) which attaches the galactose molecule to the nascent glycoprotein. Therefore the galactosyltransferase and the UDPgalactose 4-epimerase have been studied more thoroughly as a function of time after partial hepatectomy, with special attention to normal diurnal rhythms.

\section{Materials and Methods}

\section{Materials}

Animals. Male Wistar rats (Ivanovas, Kisslegg, Germany), weighing about $210 \mathrm{~g}$ each, were fed on a commercial diet (Altromin; Altromin G.m.b.H., Lage-Lippe, Germany) and water given ad libitum. The diet contained $18-20 \%(w / w)$ of protein. The animals were kept in windowless rooms at $20^{\circ} \mathrm{C}$ with constant humidity, and light from 07:30 to 19:30h. Food was only available during the dark period.

Chemicals. UDP- $\left[{ }^{14} \mathrm{C}\right]$ galactose $(245 \mathrm{mCi} / \mathrm{mmol})$, D- $\left[1-{ }^{14} \mathrm{C}\right]$ galactose $(40 \mathrm{mCi} / \mathrm{mmol}), \mathrm{D}-\left[\mathrm{U}-{ }^{14} \mathrm{C}\right] \mathrm{galac}-$ tose 1-phosphate $(200 \mathrm{mCi} / \mathrm{mmol})$ and $\left[{ }^{14} \mathrm{C}\right]$ toluene were obtained from The Radiochemical Centre, 
Amersham, Bucks., U.K. The substrates UDPgalactose, UDP-glucose, galactose 1-phosphate, the coenzymes ATP and NAD ${ }^{+}$, and the enzyme UDPglucose-NAD ${ }^{+}$oxidoreductase (EC 1.1.1.22) were supplied by Boehringer Mannheim G.m.b.H. (Mannheim, Germany). Fetuin from foetal calf serum and dithiothreitol came from Sigma Chemical Co. (St. Louis, Mo., U.S.A.). Actinomycin D was bought from Bayer A.G. (Werk Elberfeld, Germany) and bovine serum albumin (electrophoretic purity $100 \%$ ) was from Behringwerke A.G. (Marburg/Lahn, Germany). All other chemicals of analytical grade were obtained from E. Merck A.G. (Darmstadt, Germany).

\section{Methods}

Partial hepatectomy and sham operation. After 3 weeks of a controlled lighting and feeding schedule, partial hepatectomies (Higgins \& Anderson, 1931) were performed between 08:30 and 10:00h, twothirds of the liver being removed while the animals were kept under light ether anaesthesia. Control animals were subjected to sham operations by opening the abdominal cavity by a midline incision. Before the cavity was closed again, the liver was pulled out for a moment.

Preparation of cell extract. The livers were quickly removed while the animals were under light ether anaesthesia. The tissue $(1-2 \mathrm{~g})$ was transferred to $4 \mathrm{vol}$. of chilled homogenizing medium, containing potassium phosphate (50mM), EDTA $(5 \mathrm{~mm}), \mathrm{N}$ acetylcysteine ( $4 \mathrm{~mm})$, bovine plasma albumin $(0.1 \mathrm{mg} /$ $\mathrm{ml}$ ) adjusted to pH7.5 with $1 \mathrm{M}-\mathrm{NaOH}$ (Walker \& Khan, 1968). The tissue was homogenized for 40-50s with a Torpedo homogenizer (Emmendingen Maschinenbau G.m.b.H., Emmendingen, Germany) equipped with a thyristor regulator (Janke und Kunkel K.G., Staufen, Germany). Portions of this homogenate were used for the determination of UDPgalactose-glycoprotein galactosyltransferase activity. The mixture was centrifuged for $30 \mathrm{~min}$ at $30000 \mathrm{~g}$. The supernatant fraction was diluted by addition of $4 \mathrm{vol}$. of the phosphate buffer described above (pH7.5). All enzymes were assayed within $2 \mathrm{~h}$ after removal of the liver.

Assays. The galactokinase (ATP-D-galactose 1phosphotransferase, EC 2.7.1.6) was measured by a radiochemical assay as described by Sherman \& Adler (1963). The standard assay mixture in a final volume of $0.2 \mathrm{ml}(\mathrm{pH} 8)$ contained glycylglycine $(25 \mu \mathrm{mol})$, ATP $(1 \mu \mathrm{mol}), \mathrm{MgCl}_{2}(1.5 \mu \mathrm{mol}), \mathrm{NaF}$ $(1 \mu \mathrm{mol})$, dithiothreitol $(0.8 \mu \mathrm{mol}), \mathrm{D}-\left[1-{ }^{14} \mathrm{C}\right] \mathrm{galactose}$ $(0.2 \mu \mathrm{mol})$ and approx. $30 \mu \mathrm{l}$ of supernatant fraction (0.14-0.20 mg of protein). Incubations were carried out for $10 \mathrm{~min}$ at $30^{\circ} \mathrm{C}$. The reaction was terminated by placing the Eppendorf cups in boiling water for 90s. Afterwards $100 \mu \mathrm{l}$ of the assay mixture was applied to Whatman no. 3 paper and chromatographed for $18-20 \mathrm{~h}$ with ethanol/1 M-ammonium acetate, pH7.5 (5:2, v/v) (Paladini \& Leloir, 1952). Blank incubation mixtures contained no ATP. The amount of radioactivity was determined by counting successively 1.0 or $2.0 \mathrm{~cm}$-wide strips in $15 \mathrm{ml}$ of toluene scintillation mixture (Kallmann et al., 1958). The unit of specific activity is expressed in $\mathrm{nmol}$ of D-galactose 1-phosphate formed/min per $\mathrm{mg}$ of protein.

For the determination of the galactose 1-phosphate uridyltransferase (UDP-glucose- $\alpha$-D-galactose 1phosphate uridylyltransferase, EC 2.7.7.12) a similar procedure was used (Bertoli \& Segal, 1966). Incubation mixtures in a final volume of $0.2 \mathrm{ml}(\mathrm{pH} 8.5)$ contained glycine $(25 \mu \mathrm{mol})$, UDP-glucose $(50 \mathrm{nmol})$, dithiothreitol $(2 \mu \mathrm{mol}), \mathrm{D}-\left[\mathrm{U}-{ }^{14} \mathrm{C}\right] \mathrm{galactose} 1$-phosphate $(68 \mathrm{nmol})$ and approx. $30 \mu \mathrm{l}$ of supernatant fraction. Blank incubation mixtures contained no UDP-glucose. For the separation and determination of UDP- $\left[{ }^{14} \mathrm{C}\right]$ galactose the same methods were used as described for the galactokinase. Units of specific activity are given as $\mathrm{nmol}$ of UDP- $\left[{ }^{14} \mathrm{C}\right]$ galactose formed/min per $\mathrm{mg}$ of protein.

UDP-galactose 4-epimerase activity (EC 5.1.3.2) was measured spectrophotometrically by following the formation of NADH at $334 \mathrm{~nm}$ and $30^{\circ} \mathrm{C}$ (Maxwell, 1957). The assay mixture (pH8.7) contained NAD ${ }^{+}(1.3 \mu \mathrm{mol})$, UDP-galactose $(0.14 \mu \mathrm{mol})$, glycine $(350 \mu \mathrm{mol})$ and UDP-glucose dehydrogenase ( 0.1 unit) in a final volume of $0.75 \mathrm{ml}$. The reaction was initiated by the addition of UDP-galactose and observed for $5 \mathrm{~min}$.

The activity of the UDP-galactose-glycoprotein galactosyltransferase, a marker enzyme of the Golgi apparatus, was measured in a radiochemical assay with desialylated and degalactosylated fetuin (see below) as acceptor. The total volume of the incubation mixture (pH6.75) was $0.1 \mathrm{ml}$, containing sodium cacodylate $(6 \mu \mathrm{mol}), \mathrm{MnCl}_{2}(1.2 \mu \mathrm{mol}), \mathrm{MgCl}_{2}$ $(0.2 \mu \mathrm{mol})$, dithiothreitol $(1 \mu \mathrm{mol})$, UDP-D-[1-14 $\mathrm{C}]-$ galactose $(0.1 \mu \mathrm{mol})$, fetuin $(0.5 \mathrm{mg}), 10 \mu \mathrm{l}$ of $5 \%(\mathrm{v} / \mathrm{v})$ Triton X-100 and $20 \mu \mathrm{l}$ of the liver homogenate (0.3-0.4 mg of protein). Blank incubation mixtures contained native fetuin. Incubation was carried out for $30 \mathrm{~min}$ at $30^{\circ} \mathrm{C}$. The reaction was stopped by placing the Eppendorf cups in boiling water for $90 \mathrm{~s}$. The protein-bound radioactivity was determined by the method of Mans \& Novelli (1960) with slight modifications. The incubation mixture was pipetted on to filter-paper discs (Whatman $3 \mathrm{MM}, 2.3 \mathrm{~cm}$ diam.) which had been mounted on pins. The discs were dried and transferred to chilled $10 \%(w / v)$ trichloroacetic acid to precipitate the protein. The discs were left for $60 \mathrm{~min}$ at $4^{\circ} \mathrm{C}$ and then subjected to the following washing procedure: $30 \mathrm{~min}$ at $4^{\circ} \mathrm{C}$ in $5 \%$ (w/v) trichloroacetic acid, $30 \mathrm{~min}$ at $22^{\circ} \mathrm{C}$ in ether/ 
ethanol $(1: 1, \mathrm{v} / \mathrm{v})$, and finally $15 \mathrm{~min}$ in ether. Radioactivity was determined by counting the air-dried discs in toluene scintillation mixture.

Preparation of desialylated and degalactosylated fetuin. Sialic acid was removed from foetal calf serum fetuin by acid hydrolysis with $0.02 \mathrm{M}-\mathrm{H}_{2} \mathrm{SO}_{4}$ for 60 min at $80^{\circ} \mathrm{C}$. Galactose was removed by the method of Spiro (1964), which involves periodate oxidation, borohydride reduction and mild acid hydrolysis.

Determination of sugar nucleotides. UDP-glucose and UDP-galactose were determined essentially as described by Keppler et al. (1970). Liver samples were obtained in situ by the freeze-clamp technique (Wollenberger et al., 1960). The frozen tissue was transferred to $3 \mathrm{vol}$. of chilled $0.9 \mathrm{M}-\mathrm{HClO}_{4}$ and immediately homogenized with a motor-driven Potter-Elvehjem homogenizer and Teflon pestle for $1 \mathrm{~min}$ at $3000 \mathrm{rev} . / \mathrm{min}$. The suspensions were centrifuged for $15 \mathrm{~min}$ at $18000 \mathrm{~g}$, the supernatants being carefully decanted and collected, whereas the sediments were rehomogenized in $1.5 \mathrm{vol}$. of $0.6 \mathrm{M}$ $\mathrm{HClO}_{4}$. After a second centrifugation the supernatants were combined with the first ones and neutralized with $\mathrm{KOH}$ until a pH of 7.5 was reached. $\mathrm{KClO}_{4}$ was removed by centrifugation for $10 \mathrm{~min}$ at $10000 \mathrm{~g}$ and the clear supernatant was used for the determination of sugar nucleotides. The standard assay mixture in a final volume of $0.7 \mathrm{ml}(\mathrm{pH} 8.5)$ contained glycine $(500 \mu \mathrm{mol}), \mathrm{NAD}^{+}(1.5 \mu \mathrm{mol})$, EDTA $(4 \mu \mathrm{mol})$ and $200 \mu \mathrm{l}$ of neutralized liver extract. The reaction was initiated by the addition of UDP-glucose dehydrogenase (0.1 unit). When no further increase of extinction could be observed UDP-galactose 4-epimerase ( 0.1 unit) was added to determine the content of UDP. galactose.

Protein determination. The protein content of the supernatant fraction was determined by the method of Lowry et al. (1951). For homogenates the biuret method was preferred (Beisenherz et al., 1953). Before the addition of biuret reagent, protein was precipitated either by $10 \%(w / v)$ trichloroacetic acid or by dioxan. Crystalline bovine serum albumin was used as a standard.

\section{Results}

UDP-galactose 4-epimerase. After a lag period of about $6 \mathrm{~h}$, the activity increased threefold, reaching a maximum of $15 \mathrm{nmol} / \mathrm{mg}$ of protein 4 days after partial hepatectomy (Fig. 1). Sham-operated animals showed no striking changes. Only a slight increase in enzyme activity was measured within $24 \mathrm{~h}$ after operation, which gradually declined thereafter.

When the activity is expressed in $\mathrm{nmol} / \mathrm{g}$ wet wt. of liver the enzyme pattern does not change, except that at day 4 after partial hepatectomy only a 2.6 -fold increase of epimerase activity is calculated. This fact

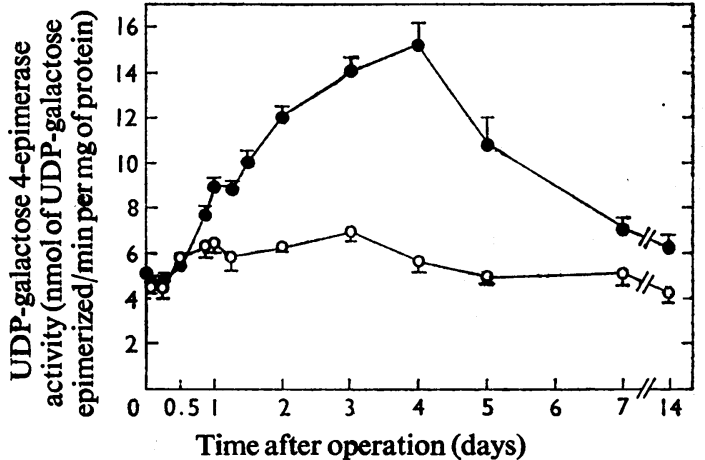

Fig. 1. Pattern of UDP-galactose 4-epimerase activity in rat liver

Enzyme activity was measured spectrophotometrically in a linked assay system by following the formation of UDPglucose coupled to nicotinamide nucleotide reduction at $334 \mathrm{~nm}$ and $30^{\circ} \mathrm{C}$. $\odot$, Partial hepatectomy; $O$, sham operation. Each point represents the mean \pm S.E.M. for five rats.

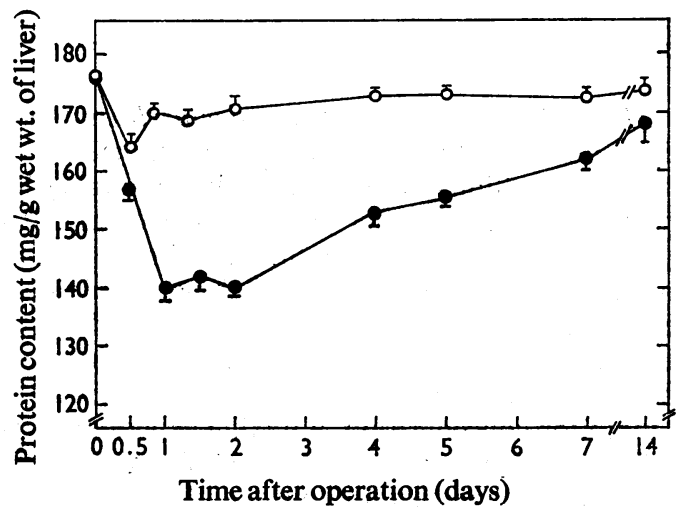

Fig. 2. Restoration of protein content in rat liver after partial hepatectomy

The protein content was measured by the biuret method. -, Partial hepatectomy; $\bigcirc$, sham operation. Each point is the mean \pm s.E.M. for five animals.

is a result of increased protein concentration. Up to $24 \mathrm{~h}$ after partial hepatectomy the protein content/g wet wt. of liver decreased, and remained at this low value for another $24 \mathrm{~h}$ before it started to rise. Usual concentrations of protein were attained approx. 14 days after partial hepatectomy (Fig. 2). The effect of UDP-galactose on epimerase activity was determined and the data obtained were plotted by the method of Lineweaver \& Burk (1934). The Michaelis constants were calculated as $30 \mu \mathrm{M}$ for rat liver epimerase 4 days after partial hepatectomy and $32 \mu \mathrm{M}$ for the epimerase of sham-operated animals. 


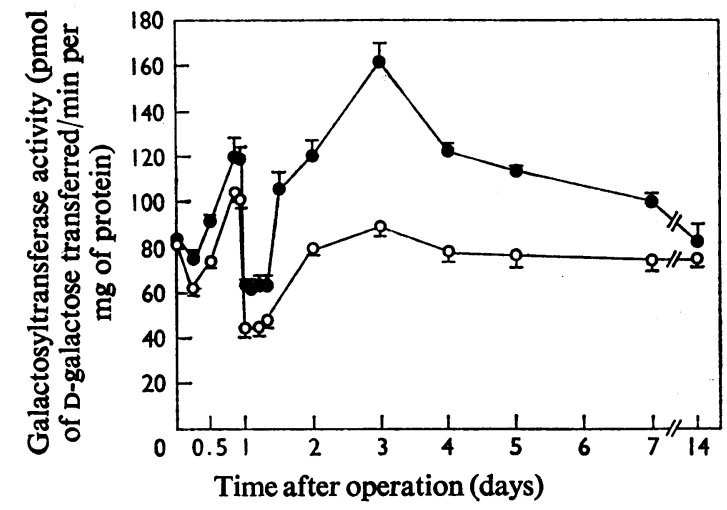

Fig. 3. Pattern of UDP-galactose-glycoprotein galactosyltransferase

Enzyme activity was determined in a radiochemical assay by measuring the transfer of $\left[{ }^{14} \mathrm{C}\right]$ galactose to desialized and degalactosylated fetuin at $30^{\circ} \mathrm{C}$. For further experimental details see the Materials and Methods section. Partial hepatectomy; $O$, sham operation. Each point represents the mean \pm S.E.M. for five rats.

UDP-galactose-glycoprotein galactosyltransferase. Fig. 3 shows that the specific activity of the galactosyltransferase exhibits two peaks, the first occurring $20 \mathrm{~h}$ and the second $72 \mathrm{~h}$ after partial hepatectomy. It is remarkable that after the first maximum a pronounced decrease occurred, reaching a minimum between 24 and $32 \mathrm{~h}$ which was less than $25 \%$ of the value for non-operated controls. To exclude the possibility that the low activity was due to an increase in inhibitor concentration, a mixing experiment was performed. Homogenate prepared from rats $26 \mathrm{~h}$ after partial hepatectomy was added to control extracts, with the result that no inhibition of the galactosyltransferase was found.

During the first $24 \mathrm{~h}$ a similar pattern of galactosyltransferase was found in sham-operated animals. However, in contrast with partially hepatectomized rats the enzyme activity at $72 \mathrm{~h}$ did not exceed normal values.

The $K_{\mathrm{m}}$ value was calculated to be $59 \mu \mathrm{M}$-UDPgalactose for the galactosyltransferase of shamoperated animals. After partial hepatectomy no change of $K_{\mathrm{m}}$ was found.

Diurnal rhythm. When investigating the pattern of enzymes it is necessary to know their normal daily rhythm, because a change after partial hepatectomy may only reflect diurnal variation of enzyme activity. Under a controlled lighting and feeding schedule the epimerase as well as the galactosyltransferase showed their highest activity at the end of the dark period between 07:00 and 08:00 h (Fig. 4). During the day, when the animals were resting, the enzyme
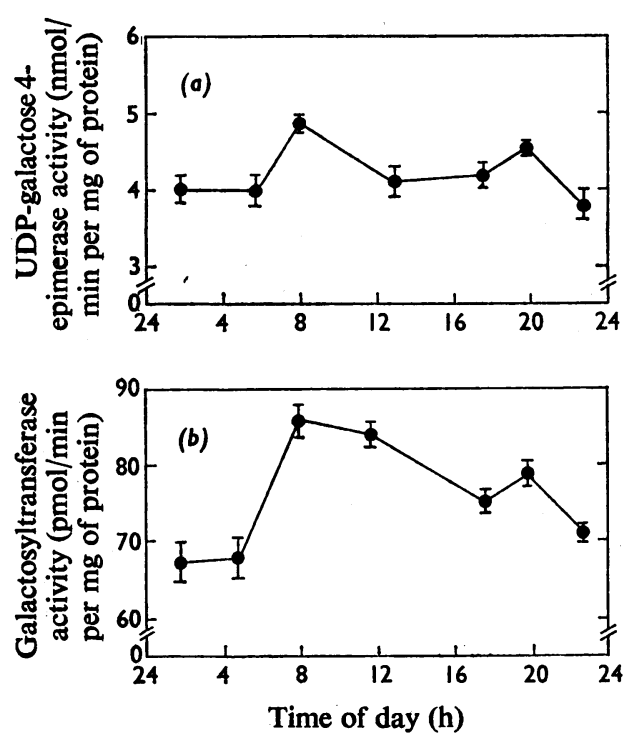

Fig. 4. Enzyme activities at various times of the day

(a) UDP-galactose 4-epimerase activity; (b) UDP-galactose-glycoprotein galactosyltransferase activity. Each point represents the mean \pm S.E.M. from five rats. $P<0.005$ for difference between minimal $(02: 00 \mathrm{~h})$ and maximal activity $(08: 00 \mathrm{~h})$ of UDP-galactose 4-epimerase and UDP-galactose-glycoprotein galactosyltransferase.

activity decreased. Yet the lowest values were not found at 19:30h, when the light was switched off and food was available again, but between midnight and 04:00h.

Effect of actinomycin D on enzyme activity. To prove a direct relationship between RNA synthesis and the increased activities of the epimerase and galactosyltransferase, the rats received a single injection of $1 \mathrm{mg}$ of actinomycin $\mathrm{D} / \mathrm{kg}$ body wt. (Fig. 5). When actinomycin is injected immediately after partial hepatectomy (Short et al., 1975) it can most effectively suppress the increase of enzyme activity. At $24 \mathrm{~h}$ after the operation the activity of the epimerase was inhibited by $50 \%$, compared with operated animals which received no antibiotic, but an injection of $0.9 \% \mathrm{NaCl} /$ ethanol. When actinomycin was administered at a later time it could still block the stimulation of enzyme activity, but only to a lesser extent.

Concerning the galactosyltransferase, the administration of actinomycin D can even induce a limited superinduction. At 4 and 5 days after partial hepatectomy (the antibiotic was injected $18 \mathrm{~h}$ before death) the activity of the galactosyltransferase was $20 \%$ higher as compared with controls. This finding will be discussed below in more detail. There was little effect of actinomycin D on the enzyme activity in sham-operated rats. 
Galactokinase and galactose 1-phosphate uridyltransferase. The activities of both enzymes increased after operation but in contrast with the epimerase and galactosyltransferase there was hardly any difference between the enzyme patterns after partial hepatectomy and sham operation. The galactokinase

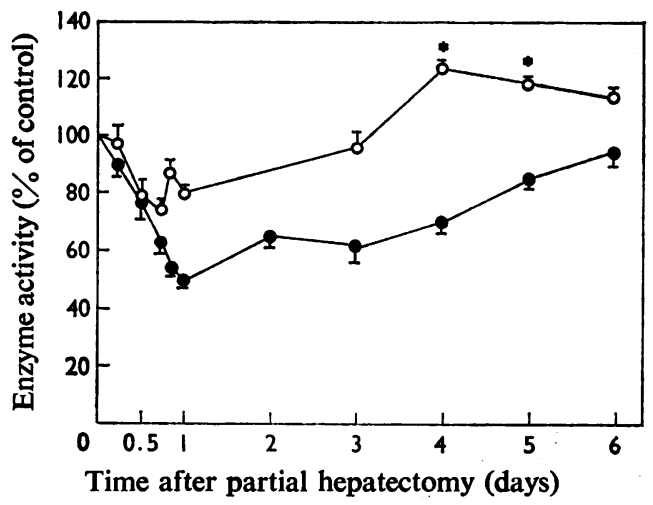

Fig. 5. Effect of actinomycin D on enzyme activity

The first group of animals, killed $6,12,18$ or $24 \mathrm{~h}$ after partial hepatectomy, received an injection of $1 \mathrm{mg}$ of actinomycin $\mathrm{D} / \mathrm{kg}$ body wt. immediately after the operation. The second group, killed 2, 3, 4 or 5 days after partial hepatectomy, was given the same dose $18 \mathrm{~h}$ before death. The antibiotic was dissolved in $50 \%(\mathrm{v} / \mathrm{v})$ ethanol and adjusted to $10 \mathrm{ml}$ with $0.9 \%$ (w/v) NaCl. Control animals received a solution of $0.9 \% \mathrm{NaCl} /$ ethanol without actinomycin D. Each point represents the mean \pm s.E.M. from six rats. ${ }^{*} P<0.02$ as compared with untreated controls. activity increased 2.5 -fold within $24 \mathrm{~h}$, whereas the uridyltransferase activity rose only by $20 \%$ as compared with sham-operated controls.

Concentration of sugar nucleotides. The substrates for the epimerase and galactosyltransferase, UDPglucose and UDP-galactose respectively, were measured at different times after partial hepatectomy (Table 1). Immediately after the operation the concentration of UDP-glucose decreases, reaching a minimum of $70 \%$ of the normal value between 3 and $6 \mathrm{~h}$. This intracellular loss is compensated for at $16 \mathrm{~h}$ after partial hepatectomy. The decrease in UDPglucose is almost paralleled by UDP-galactose, with the consequence that the ratio UDP-glucose/UDPgalactose remains in the normal range of 3.2-3.7:1.0. In comparison with partial hepatectomy, sham operation produces a rise to higher concentrations of both sugar nucleotides. Already $3 \mathrm{~h}$ after operation normal values are reached again, followed by a shorter-lasting overshoot of the values for UDP-glucose and UDPgalactose.

\section{Discussion}

Since galactose is an essential constituent of membrane glycoproteins and glycolipids, studies on galactose metabolism may contribute to an understanding of processes initiated in regenerating rat liver.

After a lag period of about $6 \mathrm{~h}$, probably owing to operation stress, the activity of galactose-metabolizing enzymes increases. Partial hepatectomy caused a threefold increase in the activity of UDP-galactose 4-epimerase, with a maximum 4 days after operation. The enzyme pattern of the galactosyltransferase was biphasic, the first peak of activity appearing at $20 \mathrm{~h}$ after partial hepatectomy, the second at $72 \mathrm{~h}$.

\section{Table 1. Time-course of sugar nucleotide concentration}

Partial hepatectomies and sham operations were performed between 08:30 and 10:00h. At the times indicated, liver lobes were instantly frozen in situ between metal tongs precooled in liquid $\mathrm{N}_{2}$ (Wollenberger et al., 1960). The sugar nucleotides were determined in a neutralized $\mathrm{HClO}_{4}$ extract. For further experimental details see the Materials and Methods section. Values are means \pm S.D. from five rats. ${ }^{*} P<0.01$ as compared with sham-operated animals.

Concentration of sugar nucleotides (nmol/g wet wt. of liver)

\begin{tabular}{|c|c|c|c|c|}
\hline \multirow[b]{3}{*}{ Time after operation (h) } & \\
\hline & \multicolumn{2}{|c|}{ UDP-glucose } & \multicolumn{2}{|c|}{ UDP-galactose } \\
\hline & Partial hepatectomy & Sham operation & Partial hepatectomy & Sham operation \\
\hline $\begin{array}{c}1 \\
3 \\
6 \\
10 \\
24 \\
48 \\
72 \\
96 \\
336 \\
\text { Control (unoperated animals) }\end{array}$ & $\begin{array}{l}273 \pm 20 \\
232 \pm 32^{*} \\
243 \pm 35^{*} \\
294 \pm 27^{*} \\
385 \pm 28 \\
378 \pm 34 \\
376 \pm 28 \\
334 \pm 41 \\
332 \pm 37 \\
331 \pm 25\end{array}$ & $\begin{array}{l}235 \pm 28 \\
322 \pm 18 \\
338 \pm 30 \\
417 \pm 40 \\
404 \pm 32 \\
357 \pm 30 \\
320 \pm 24 \\
357 \pm 51 \\
336 \pm 40\end{array}$ & $\begin{array}{r}90 \pm 8 \\
72 \pm 10 \\
73 \pm 13 \\
90 \pm 7 \\
108 \pm 9 \\
105 \pm 9 \\
107 \pm 11 \\
103 \pm 12 \\
89 \pm 9 \\
92 \pm 7\end{array}$ & $\begin{array}{r}84 \pm 10 \\
87 \pm 4 \\
102 \pm 10 \\
129 \pm 15 \\
110 \pm 12 \\
94 \pm 9 \\
95 \pm 12 \\
94 \pm 13 \\
91 \pm 5\end{array}$ \\
\hline
\end{tabular}

Vol. 154 
The data presented here show quite clearly that the rise in enzyme activity is due to synthesis of enzyme protein de novo. Actinomycin D, a potent inhibitor of protein synthesis, blocked the increase completely, provided that the antibiotic was administered immediately after partial hepatectomy. At a later point of time actinomycin D is less effective. Akamatsu \& Maeda (1971) reported a similar result for glucosamine 6-phosphate synthetase. Moreover, when actinomycin $D$ is injected 4 days after partial hepatectomy, the activity of galaotosyltransferase does not decrease, but increases further. This phenomenon, referred to as superinduction, was first described for tryptophan pyrrolase (Garren et al., 1964). It may be possible that after partial hepatectomy, when the activity of galactosyltransferase is maximal, an actinomycin-sensitive repressor appears. By blocking the synthesis of this repressor, the activity of the galactosyltransferase is raised. Further work is required to solve this problem.

Not only the inhibition experiments with antibiotics but also the determination of enzyme characteristics support the conclusion that there is synthosis of enzyme protein de novo. The $K_{\mathrm{m}}$ values for the epimerase and galactosyltransferase in both normal and regenerating liver show no differences. On the basis of these findings it is unlikely that the increased activity of enzymes after partial hepatectomy is caused by modifying effectors.

Rapid proliferation of hepatocytes is found normally in foetal and neonatal rat liver. Therefore it is interesting to compare the characteristics of galactosemetabolizing enzymes in perinatal and adult rats with those results obtained after partial hepatectomy. The activities of galactokinase (Cuatrecasas \& Segal, 1965) and of galactose 1-phosphate uridyltransferase (Bertoli \& Segal, 1966) increase a few days before birth and reach a maximum at 5-10 days of age respectively. No evidence of enzyme heterogeneity could be found, and the $K_{\mathrm{m}}$ values and other kinetic parameters of the galactokinase remain constant during development (Walker \& Khan, 1968). Similar results are reported for the UDP-galactose 4-epimerase (Cohn \& Segal, 1969) and UDP-galactoseglycoprotein galactosyltransferase (Jato-Rodriguez \& Mookerjea, 1974), except that these enzymes show their highest activities in the perinatal period and decrease rapidly within a few days. The $K_{\mathrm{m}}$ value of $55 \mu \mathrm{M}$-UDP-galactose for both foetal and adult liver galactosyltransferase does not differ from data obtained after partial hepatectomy.

It is noteworthy that not only the epimerase and galactosyltransferase change their activity after partial hepatectomy, but at the same time alterations in the concentration of sugar nucleotides are found. The decrease in UDP-glucose and UDP-galactose immediately after operation is not due to enhanced accumulation of glycogen in the liver remnant. On the contrary, up to $24 \mathrm{~h}$ after operation the glycogen content decreases, and returns to normal after $48 \mathrm{~h}$ (Bonney et al., 1973). It is more likely that the lowered content of UDP-glucose is caused by a decreased rate of synthesis. It is known that the hexokinase activity increases (Lea et al., 1970) and phosphoglucomutase activity remains constant (Weber \& Cantero, 1957) after partial hepatectomy. Moreover, the coenzyme UTP, necessary for the synthesis of UDP-glucose, increases by $50 \%$ within $3 \mathrm{~h}$ after partial hepatectomy (Bucher \& Swaffield, 1969). The major part of the glycogen in the liver remnant is used either by glycolysis or to maintain a sufficient blood glucose concentration.

This work was supported by the Deutsche Forschungsgemeinschaft, Bad Godesberg, Germany.

\section{References}

Akamatsu, N. \& Maeda, H. R. (1971) Biochim. Biophys. Acta 244, 311-317

Beisenherz, G., Boltze, H. J., Bücher, Th., Czok, R., Garbade, K. H., Meyer-Arendt, E. \& Pfleiderer, G. (1953) Z. Naturforsch. Teil B 8, 555-577

Bertoli, D. \& Segal, S. (1966) J. Biol. Chem. 241, 40234029

Bonney, R., Hopkins, H., Walker, P. \& Potter, V. R. (1973) Biochem. J. 136, 115-124

Bucher, N. \& Swaffield, M. (1969) Biochim. Biophys. Acta 174, 491-502

Bucher, N. \& Swaffield, M. (1973) Cancer Res. 33, 31893194

Chatterjee, J., Pal, D. R., Majumder, P. K. \& Chatterjee, G. C. (1974) Biochem. Pharmacol. 23, 752-754

Chaudhuri, S. \& Lieberman, I. (1968) J. Biol. Chem. 243, 29-33

Cohn, R. \& Segal, S. (1969) Biochim. Biophys. Acta 171, 333-341

Cuatrecasas, P. \& Segal, S. (1965) J. Biol. Chem. 240, 2382-2388

Eylar, E. H. \& Jeanloz, R. W. (1962) J. Biol. Chem. 237, 622-628

Garren, L. D., Howell, R. R., Tomkins, G. M. \& Crocco, R. M. (1964)Proc. Natl. Acad. Sci. U.S.A. 52, 1121-1129

Grisham, J. W. (1962) Cancer Res. 22, 842-849

Henning, R. \& Stoffel, W. (1973) Hoppe-Seyler's $Z$. Physiol. Chem. 354, 760-770

Higgins, G. M. \& Anderson, R. M. (1931) Arch.Pathol. 12, 186-202

Jänne, J. \& Raina, A. (1968) Acta Chem. Scand. 22, 13491351

Jato-Rodriguez, J. J. \& Mookerjea, S. (1974) Arch. Biochem. Biophys. 162, 281-292

Kallmann, H., Hayes, F. N. \& Furst, M. (1958) in LiquidScintillation Counting (Bell, C. G. \& Hayes, F. N., eds.), p. 56, Pergamon Press, New York

Keppler, D., Rudigier, J. \& Decker, K. (1970) Anal. Biochem. 38, 105-114

Lea, M., Sasovetz, D., Musella, A. \& Morris, H. P. (1970) Cancer Res. 30, 1994-1999 
Lineweaver, H. \& Burk, D. (1934) J. Am. Chem. Soc. 56, 658-666

Lowry, O. H., Rosebrough, N. J., Farr, A. L. \& Randall, R. J. (1951) J. Biol. Chem. 193, 265-275

Mans, R. J. \& Novelli, G. D. (1960) Biochem. Biophys. Res. Commun. 3, 540-543

Maxwell, E. S. (1957) J. Biol. Chem. 229, 139-151

Mayfield, J. E. \& Bonner, J. (1972) Proc. Natl. Acad. Sci. U.S.A. 69, 7-10

Paladini, A. C. \& Leloir, L. F. (1952) Biochem. J. 51, 426430

Paul, D., Leffert, H., Sato, G. \& Holley, R. (1972) Proc. Natl. Acad. Sci. U.S.A. 69, 347-377

Pekarthy, J. M., Short, J., Lansing, A. I. \& Lieberman, I. (1972) J. Biol. Chem. 247, 1767-1774
Russell, D. \& Snyder, S. H. (1968) Proc. Natl. Acad. Sci. U.S.A. 60, 1420-1427

Sherman, J. R. \& Adler, J. (1963) Anal. Biochem. 5, 548554

Short, J., Armstrong, N. B., Gaza, D. J. \& Lieberman, I. (1975) in Liver Regeneration after Experimental Injury (Lesch, R. \& Reutter, W., eds.), pp. 296-308, Stratton Intercontinental Medical Book Corporation, New York

Spiro, R. G. (1964) J. Biol. Chem. 239, 567-573

Walker, D. G. \& Khan, H. H. (1968) Biochem. J. 108, 169-175

Weber, G. \& Cantero, A. (1957) Cancer Res. 17, 995-1005

Wollenberger, A., Ristau, O. \& Schoffa, G. (1960) Pflügers Arch. Gesamte Physiol. Menschen Tiere 270, 399-412 